\title{
Pengaruh variasi campuran bahan bakar tongkol jagung dan tempurung kelapa terhadap unjuk kerja tungku biomassa
}

I.W. Joniarta*, M. Wijana, A.A.Alit Triadi, I.B.K.T.H. Iswara, I.G.A.K.C. Adhi

Teknik Mesin Fakultas Teknik Universitas Mataram, Jln. Majapahit No. 62 Mataram Nusa Tenggara Barat Kode Pos : 83125, Telp. (0370) 636087

*Email:wayanjoniarta@unram.ac.id

\section{ARTICLE INFO}

Article History:

Received 18 October 2017

Accepted 30 April 2018

Available online 1 July 2018

Keywords:

Furnace

Biomass

Performance

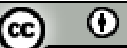

\begin{abstract}
Agricultural waste such as corn cobs and coconut shell can be used as alternative energy. Biomass as an alternative energy can be used as a fuel in the furnace. Corncob has low calorific value and density, so it is necessary to examine the combination's effect of corn cobs and coconut shell toward the performances of biomass furnace.The gasification furnace was the development of a furnace design on previous research. Diameter of combustion chamber is $25 \mathrm{~cm}$, diameter of free air duct and secondary air duct is $2 \mathrm{~cm}$, and primary air duct is $1 \mathrm{~cm}$. Combined corncob and coconut shell in sequence are $100 \%: 0 \%, 80 \%: 20 \%, 60 \%: 40 \%, 40 \%$ : 60\%, 20\%: 80\%, 0\%: 100\%. Investigated parameters showing the furnace performance were boiling time, FCR, power input, power output, power loss and efficiency are boiling time, FCR, operating time, power input, power output, power loss and efficiency. Test of operating time were conducted by burning fuel until burned out. Then boiling time test were conducted by heated 1 liters water from ambient temperature to boiling (between $95^{\circ} \mathrm{C}$ $97^{\circ} \mathrm{C}$ ) on a $24 \mathrm{~cm}$ diameter pan. The results showed that the largest operating time (1317.33 Seconds), smallest FCR (2.249 Kg/hour), smallest power loss (19.532 kW), and the highest efficiency (8.19\%) obtained at 0\% : 100\% combination. The fastest boiling time (157 Seconds) and the largest power output $(1.828 \mathrm{~kW})$ was obtained at 40\%: 60\% combination. While the largest power input (29.286 kW) was obtained at 60\%: $40 \%$.
\end{abstract}

\section{PENDAHULUAN}

Indonesia pada saat ini sedang gencar mencanangkan program pemanfaatan limbah sebagai bahan bakar guna memenuhi kebutuhan energi di masa mendatang. Pengembangan yang dilakukan salah satunya adalah pemanfaatan biomassa dari limbah pertanian yang merupakan limbah padat dimanfaatkan lagi sebagai bahan bakar. Sifat dari biomassa ini pun sangat menguntungkan karena merupakan sumber 
energi yang dapat dimanfaatkan secara lestari karena sifatnya yang dapat diperbaharui. Program ini dikembangkan karena mengingat Indonesia yang merupakan negara agraris yang terletak di daerah khatulistiwa yang kaya akan potensi bioenergi yang dapat dimanfaatkan sebagai bahan bakar (cair, gas dan padat) maupun listrik (Widardo dan Suryanta, 1995).

Nusa Tenggara Barat (NTB) memiliki potensi lahan pengembangan jagung mencapai 268 ribu hektar. Pemerintah NTB telah menetapkan jagung sebagai salah satu komoditas unggulan daerah. Potensi lahan terluas ada di kabupaten Sumbawa (94,3 ribu hektar), kabupaten Bima (92,3 ribu hektar), dan kabupaten Lombok Tengah (52,9 ribu hektar). (www.programunggulan.ntbprov.go.id).

Potensi tongkol jagung untuk dijadikan sebagai bahan bakar sangatlah besar. Salah satu penggunaan tongkol jagung sebagai biomassa adalah untuk bahan bakar padat. Penggunaan tongkol jagung sebagai bahan bakar padat sudah sangat umum, akan tetapi masih ditemui beberapa macam hambatan. Salah satu hambatan yang terjadi adalah rendahnya nilai kalor dan densitas dari tongkol jagung tersebut. Kandungan nilai kalor dari tongkol jagung yaitu 15,65 MJ/kg. Dengan rendahnya nilai kalor dan densitas ini, maka dalam proses biomassai tongkol jagung ini akan sangat cepat terbakar dan tidak stabil. Selain itu, berdasarkan hasil penelitian yang dilakukan sebelumnya, diketahui bahwa dengan bahan bakar tongkol jagung sebesar 8,2 kg pada tungku biomassa, waktu operasional yang didapatkan adalah 70 menit atau dapat dikatakan laju pembakaran tongkol jagung adalah 7,03 Kg/Jam. (Tahir, 2013). Untuk mengatasi permasalahan tersebut dapat dilakukan dengan cara kombinasi bahan bakar yaitu dengan mencampurkan biomassa lain yang memiliki nilai kalor dan densitas yang lebih tinggi yaitu tempurung kelapa. Tempurung kelapa memiliki nilai kalor sebesar 20,50 MJ/kg.

Pada penelitian ini, akan digunakan kombinasi dua bahan baku (biomassa) yaitu memanfaatkan tongkol jagung dan tempurung kelapa. Penggunaan tongkol jagung akan dicampur dengan tempurung kelapa guna meningkatan kualitas dari pembakaran yang dilakukan sehingga nyala api yang dihasilkan dapat stabil dan bertahan cukup lama.

Pengujian kinerja (performance) tungku biomassa pada penelitian ini menggunakan metode Water Boiling Test (WBT) (BSN, 2013). Water Boilling Test (WBT) adalah metode pengujian yang digunakan untuk mengetahui kinerja suatu tungku dalam skala laboratorium, dimana kondisi iklim, bahan bakar (kelembaban, spesies, bentuk), jenis alat masak, pemasak termasuk cara mengoperasikan tungku dipertahankan sama disepanjang pengujian. Waktu Start-up (Start-up time) adalah waktu yang dibutuhkan dari awal penyalaan api sampai biomassa terbakar dengan baik (api stabil).

Waktu Operasional (Operating Time) adalah waktu yang dibutuhkan sejak awal bahan bakar terbakar hingga api pembakaran mati Fuel Comsumtion Rate (FCR)

$$
F C R=\frac{m_{t b}}{O T}
$$

Dengan FCR adalah Fuel Comsumtion Rate $(\mathrm{kg} / \mathrm{jam}), \quad \mathrm{m}_{\mathrm{tb}}$ adalah Massa bahan bakar terpakai $(\mathrm{Kg})\left(\mathrm{m}_{\mathrm{a}}-\mathrm{m}_{\mathrm{ak}}\right)$ dimana $\mathrm{m}_{\mathrm{a}}$ adalah Massa bahan bakar awal $(\mathrm{Kg}), \quad \mathrm{m}_{\mathrm{ka}}$ adalah massa bahan bakar akhir $(\mathrm{Kg})$, OT adalah Operating time (Jam) Boiling Time adalah waktu yang dibutuhkan untuk memanaskan air pada panci atau ketel, yaitu dihitung mulai dari meletakkan panci pada burner sampai air mendidih pada suhu antara $95^{\circ} \mathrm{C}$ sampai $97^{\circ} \mathrm{C}$. Daya bersih $\left(\mathrm{P}_{\text {out }}\right)$ adalah perbandingan antara energi yang digunakan untuk memanaskan air dengan lama waktu yang dibutuhkan untuk mencapai titik didih.

$P_{\text {out }}=\frac{M_{w} c_{p}\left(T_{f}-T_{i}\right)}{t}$

Dengan $\mathrm{P}_{\text {out }}$ adalah daya bersih $(\mathrm{kJ} / \mathrm{s}=\mathrm{Kw}), \mathrm{M}_{\mathrm{w}}$ adalah massa air $(\mathrm{Kg}), \mathrm{C}_{\mathrm{p}}$ adalah Kalor jenis air $\left(\mathrm{Kj} / \mathrm{Kg} .{ }^{\circ} \mathrm{C}\right)=4,1864 \mathrm{Kj} / \mathrm{Kg} .{ }^{\circ} \mathrm{C}, \mathrm{T}_{\mathrm{i}}, \mathrm{T}_{\mathrm{f}}$ adalah Temperatur air awal dan akhir $\left({ }^{\circ} \mathrm{C}\right)$, $\mathrm{t}$ adalah Waktu yang dibutuhkan untuk mendidihkan air (Detik). Daya pembakaran $\left(P_{\text {in }}\right)$ adalah energi panas yang terkandung didalam bahan bakar dibagi dengan waktu yang telah digunakan pada proses pembakaran.

$P_{i n}=\frac{m_{t a} L H V}{t}$

Dengan $P_{\text {in }}$ adalah daya pembakaran $(\mathrm{KJ} / \mathrm{s}=$ $\mathrm{kW}), \mathrm{m}_{\mathrm{ta}}$ adalah Massa bahan bakar terpakai untuk mendidihkan air $(\mathrm{Kg})$, LHV: Nilai kalor rendah bahan bakar $(\mathrm{Kj} / \mathrm{Kg})$

Daya yang hilang adalah daya pembakaran dikurangi dengan daya yang terpakai untuk memanaskan air

$P_{\text {loss }}=P_{\text {in }}-P_{\text {out }}$

Dengan $\mathrm{P}_{\text {loss }}$ adalah Kehilangan daya pada tungku $(\mathrm{Kj} / \mathrm{s}=\mathrm{Kw}), \mathrm{P}_{\text {in }}$ adalah daya pembakaran $(\mathrm{Kj} / \mathrm{s}=\mathrm{Kw}), \quad \mathrm{P}_{\text {out }}$ adalah daya yang digunakan untuk menaikkan suhu air $(\mathrm{Kj} / \mathrm{s}=\mathrm{Kw})$

Efisiensi tungku biomassa adalah perbandingan antara daya yang dipakai untuk memanaskan air dengan daya yang dihasilkan oleh bahan bakar (Mirmanto dkk., 2017). 
$\eta=\frac{P_{\text {out }}}{P_{\text {in }}} x 100 \%$

\section{METODE PENELITIAN}

Pada penelitian ini menggunakan dua metode penelitian yaitu studi litelatur dan studi eksperimental sedangkan untuk variabelnya digunakan variable bebas berupa campuran tempurung kelapa dan tongkol jagung, sedangkan variabel terikat yaitu Boilling Time, waktu operasional dan efisiensi yang dihasilkan dari tungku biomassa. Diagram alir dari penelitian ini data dilihat pada gambar 1 .

\section{PerancanganTungku}

Pada tahap ini dilakukan pendesainan dan pembuatan tungku, Desain tungku yang digunakan dapat dilihat pada gambar 2 sampai 5 (Joniarta dkk., 2014).

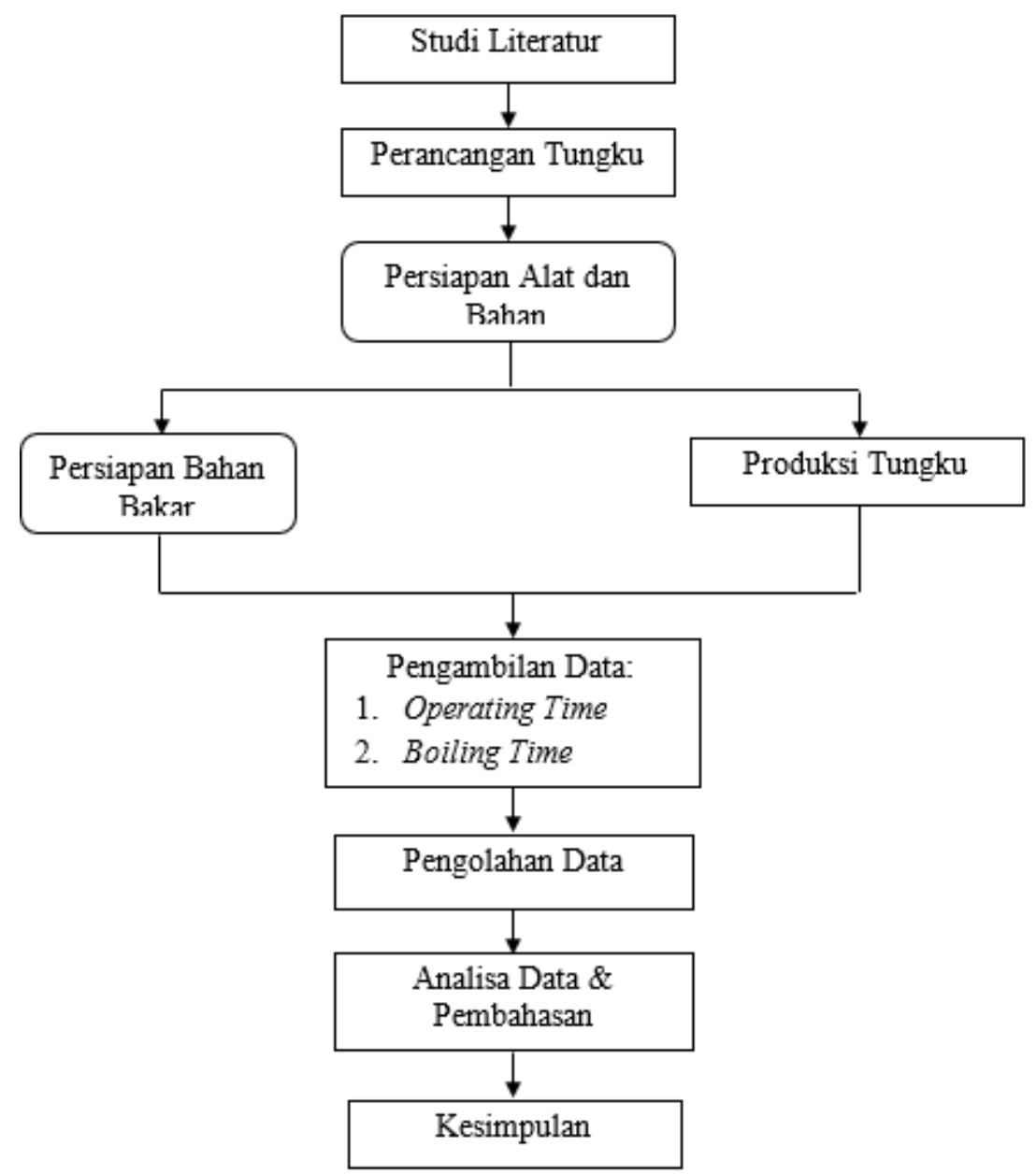

Gambar 1.Diagram alir penelitian

\section{Pengambilan Data}

1. Pengambilan data waktu operasional (operating time)

Pengambilan data dengan menggunakan bahan bakar campuran tongkol jagung : tempurung kelapa $=80 \%: 20 \%, 60 \%: 40 \%, 40 \%$ : $60 \%, 20 \%$ : $80 \%$. Langkah pengujian sebagai berikut: a. Menyiapkan bakan bakar yaitu tongkol jagung dan tempurung kelapa.

b. Menimbang berat tongkol jagung.

c. Menimbang berat tempurung kelapa.

d. Menimbang berat total bahan bakar yaitu 1 $\mathrm{kg}$.

e. Memasukkan bahan bakar ke dalam ruang bakar.

f. Menutup saluran masuk bahan bakar. 
g. Membantu penyalaan awal bahan bakar dengan minyak tanah $10 \mathrm{ml}$.

h. Memulai pencatatan waktu pada stopwatch pada saat api mulai terbentuk.

i. Menghentikan pencatatan waktu pada stopwatch saat api sudah mati. j. Menimbang massa akhir bahan bakar menggunakan timbangan digital.

k. Mengulagi prosedur a - j untuk variasi campuran tongkol jagung: tempurung kelapa 60\% : 40\%, 40\% : 60\%, 20\% : $80 \%$.

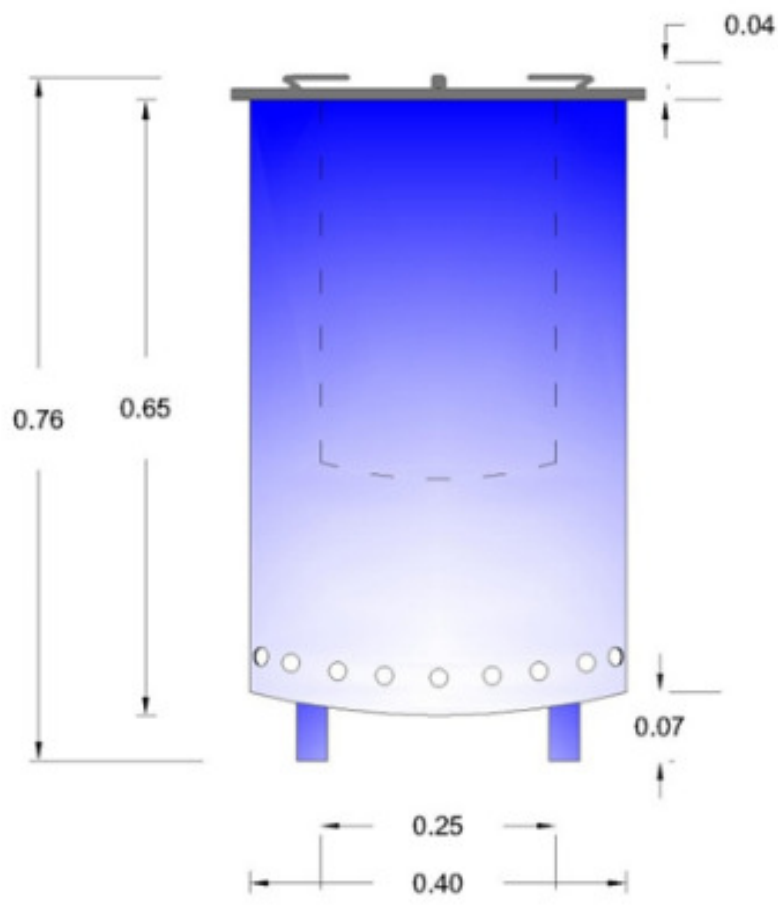

Keterangan:

Gambar 2 Tampak depan

1. Diameter Luar Tungku

2. Diameter Ruang Bakar

3. Lubang Masuk Udara Primer

4. Penyangga Wajan/ Panci

\section{Pengambilan data Boiling Time}

Pengambilan data Boiling Time dengan menggunakan bahan bakar campuran tongkol Jagung : Tempurung Kelapa = 80\%: 20\%, 60\% : 40\%, 40\%: 60\%, 20\% : 80\%. Langkah pengujian sebagai berikut:

a. Menyiapkan bakan bakar yaitu tongkol jagung dan tempurung kelapa.

b. Menimbang berat tongkol jagung.

c. Menimbang berat tempurung kelapa.

d. Menimbang berat total bahan bakar $=1 \mathrm{~kg}$.

e. Memasukkan bahan bakar ke dalam ruang bakar.

f. Menutup saluran masuk bahan bakar.

g. Membantu penyalaan awal bahan bakar dengan minyak tanah $10 \mathrm{ml}$.

h. Menyiapkan panci berisikan air bersih 1 liter

i. Menunggu sampai api menyala stabil.

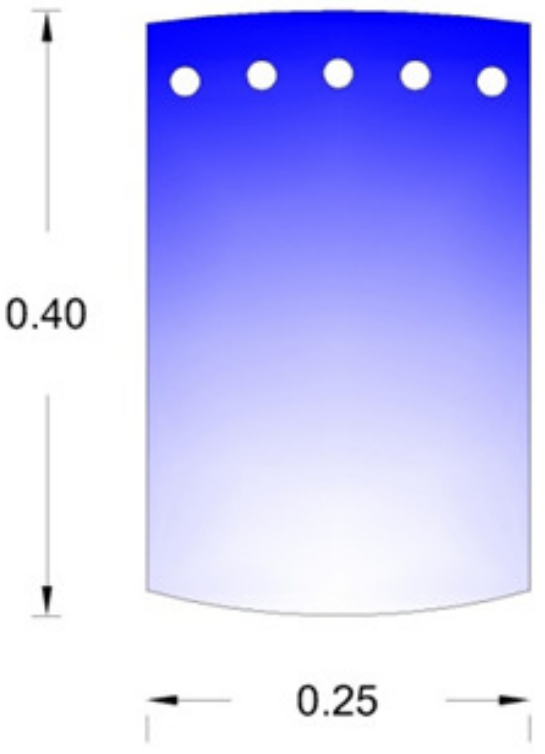

Gambar 3. Ruang bakar

j. Meletakkan panci di atas tungku saat api sudah menyala stabil.

k. Menyiapkan stopwatch untuk mengukur waktu pendidihan air.

I. Mengukur temperatur air (termometer dibiarkan di dalam panci tanpa menyentuh dasar panci untuk mengukur temperatur air per satuan waktu).

m. Menimbang massa akhir bahan bakar setelah proses pendidihan air selesai.

n. Mengulagi prosedur $a-m$ untuk variasi campuran tongkol jagung : tempurung kelapa 0\%: 100\% .

\section{HASIL DAN PEMBAHASAN}

Setelah dilakukan pengambilan data pada tiap-tiap pengujian kemudian dilakukan analisa data dan pembahasan adalag sebagai berikut: 
1. Waktu Operasional, Waktu Start-up dan Fuel Consumtion Rate

Dari gambar 6 terlihat bahwa variasi perbandingan campuran tongkol jagung dan tempurung kelapa sebagai bahan bakar berpengaruh terhadap Operating Time (OT) dan Start-up Time (ST). dimana keduanya akan meningkat. Hal ini disebabkan karena tongkol jagung memiliki kandungan sellulosa yang tinggi yang menyebabkan tongkol jagung lebih mudah terbakar, sedangkan tempurung kelapa memiliki

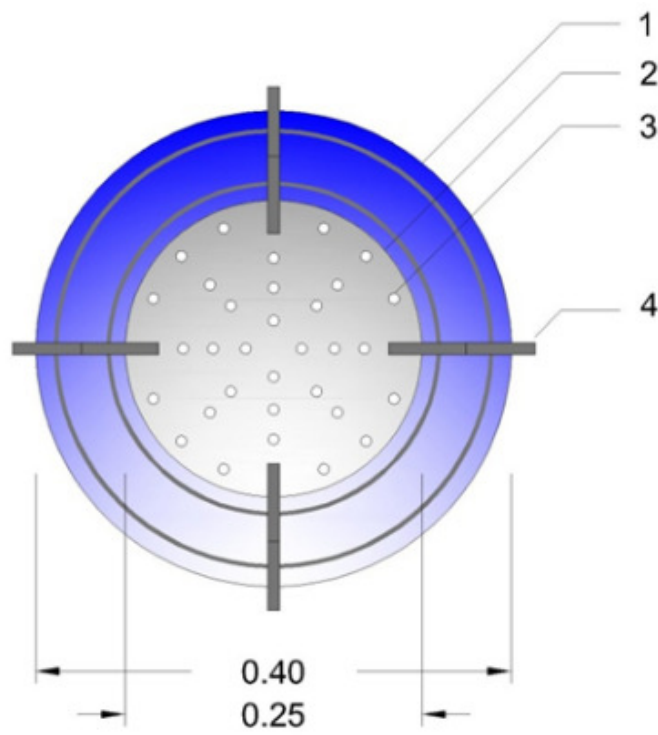

Gambar 4. Tampak atas

Dari gambar 7 dapat dilihat bahwa variasi perbandingan campuran tongkol jagung dan tempurung kelapa sebagai bahan bakar berpengaruh terhadap dengan nilai fuel comsumption rate (FCR), dimana semakin besar persentase tempurung kelapa maka nilai FCR semakin rendah. Hal ini terjadi karena densitas dan nilai kalor tempurung kelapa lebih besar dibandingkan tongkol jagung.

2. Boiling Time (BT), Daya Pembakaran $\left(P_{i n}\right)$, Daya bersih $\left(P_{\text {out }}\right)$, dan Daya Kehilangan (Ploss).

a. Boiling Time

Boiling Time dihitung mulai dari meletakkan panci pada tungku sampai air mendidih pada suhu antara $95^{\circ} \mathrm{C}-97^{\circ} \mathrm{C}$. Grafik Boiling time dapat dilihat pada gambar 8 .

Nilai boiling time pada penelitian ini bervariasi karena besarnya nilai Pout yang terjadi pada saat memanaskan air. Semakin tinggi nilai Pout maka semakin rendah (cepat) boiling time yang terjadi, dan semakin rendah nilai Pout maka semakin tinggi (lama) boiling time yang terjadi. kandungan lignin yang tinggi, yang menyebabkan tempurung kelapa lebih susah terbakar. Sedangkan Start-up Time berbanding lurus dengan Operating Time. Dimana semakin bertambahnya persentase tempurung kelapa menyebabkan semakin lama waktu yang dibutuhkan bahan bakar untuk menyala stabil. Hal ini terjadi karena densitas tempurung kelapa sebesar $661 \mathrm{~kg} / \mathrm{m}^{3}$ jauh lebih tinggi dibandingkan dengan tongkol jagung yang hanya $188 \mathrm{~kg} / \mathrm{m}^{3}$.

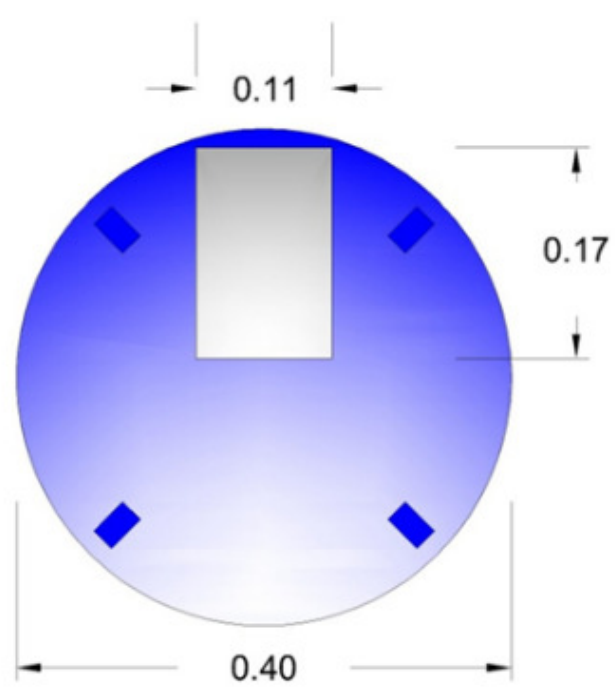

Gambar 5. Tampak bawah

Nilai Boiling Time terbaik 157 detik dicapai oleh variasi bahan bakar 40:60 \%

Nilai boiling time pada penelitian ini bervariasi karena besarnya nilai Pout yang terjadi pada saat memanaskan air. Semakin tinggi nilai Pout maka semakin rendah (cepat) boiling time yang terjadi, dan semakin rendah nilai Pout maka semakin tinggi (lama) boiling time yang terjadi. Nilai Boiling Time terbaik 157 detik dicapai oleh variasi bahan bakar 40:60 \%.

b. Daya Pembakaran $\left(P_{\text {in }}\right)$

Daya pembakaran $\left(P_{\text {in }}\right)$ adalah perbandingan antara jumlah energi panas yang yang dihasilkan oleh bahan bakar dengan jumlah bahan bakar yang dikonsumsi. Hubungan varasi campuran tongkol jagung dan tempurung kelapa terhadap $\mathrm{P}_{\text {in }}$ digambarkan dengan grafik yang dapat dilihat pada gambar 9 .

Dari Gambar 9 terlihat bahwa daya pembakaran tungku biomassai dipengaruhi oleh variasi campuran tongkol jagung dan tempurung kelapa. Campuran bahan bakar yang memiliki daya terbesar adalah campuran $60 \%$ tongkol jagung dan $40 \%$ tempurung kelapa yaitu sebesar 
29,286 kW. Sedangkan campuran bahan bakar yang memiliki daya terendah adalah 100\% tempurung kelapa yaitu 21,274 kW. Hal ini disebabkan karena tempurung kelapa memiliki densitas yang lebih tinggi dibandingkan dengan tongkol jagung, sehingga bahan bakar yang digunakan lebih lama habis dibandingkan dengan tongkol jagung. Massa rata - rata tempurung kelapa yang digunakan untuk mendidihkan 1 liter air hanya sebesar 168 gram, jauh lebih rendah dibandingkan massa rata - rata tongkol jagung yaitu sebesar 366 gram. Pada penelitian ini, semakin menurunnya nilai daya pembakaran dari variasi campuran tongkol jagung dan tempurung kelapa 40\%: $60 \%$, 20\% : $80 \%$, dan 0\%: $100 \%$ disebabkan karena semakin tinggi persentase tempurung kelapa, maka semakin sedikit volume bahan bakar yang memenuhi ruang bakar karena bentuk dari tempurung kelapa yang pipih dan padat.

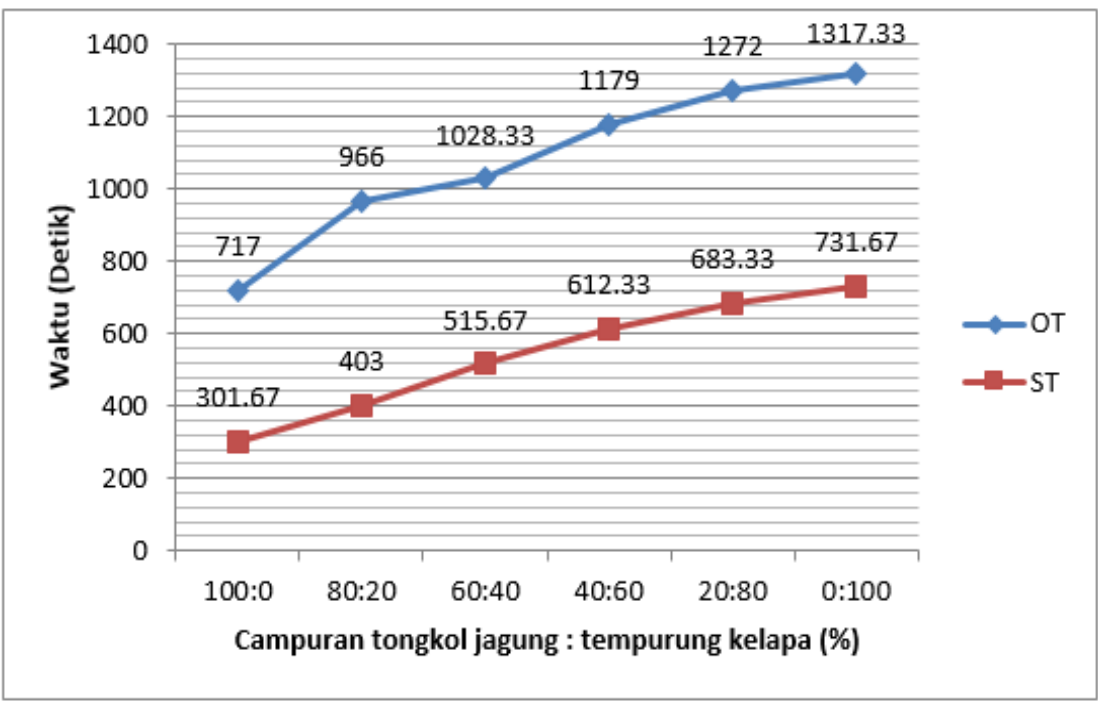

Gambar 6. Hubungan variasi campuran tongkol jagung dan tempurung kelapa terhadap Operating Time (OT) dan Start-up Time (ST)

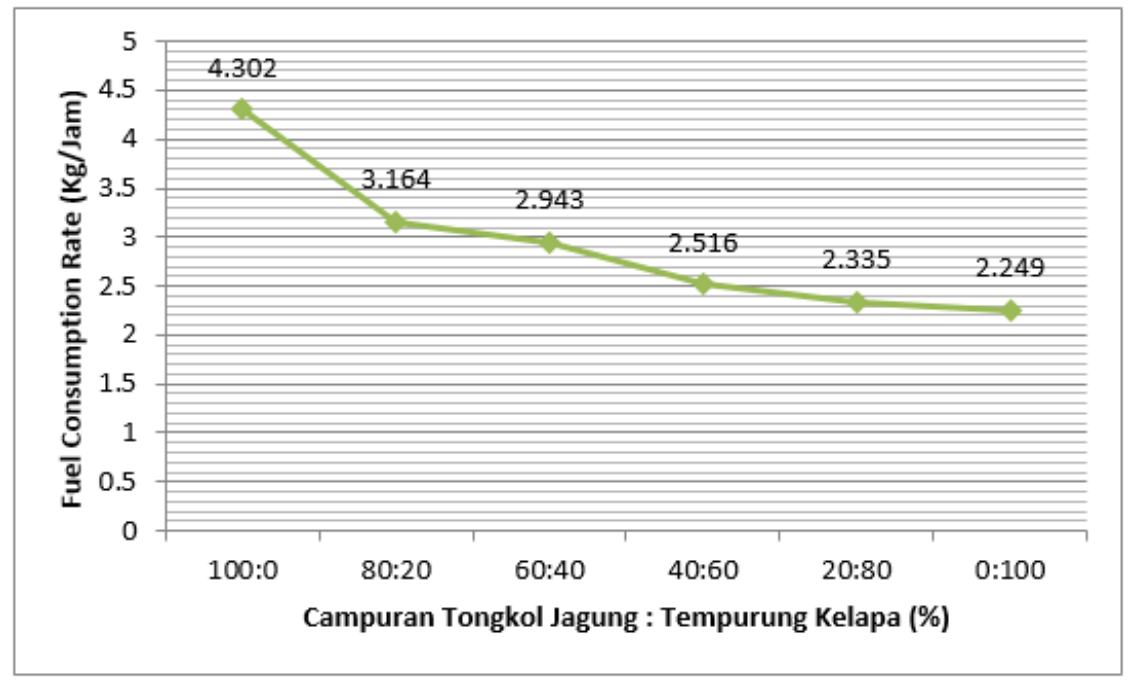

Gambar 7. Hubungan variasi campuran tongkol jagung dan tempurung kelapa terhadap Fuel Consumption Rate (FCR). 


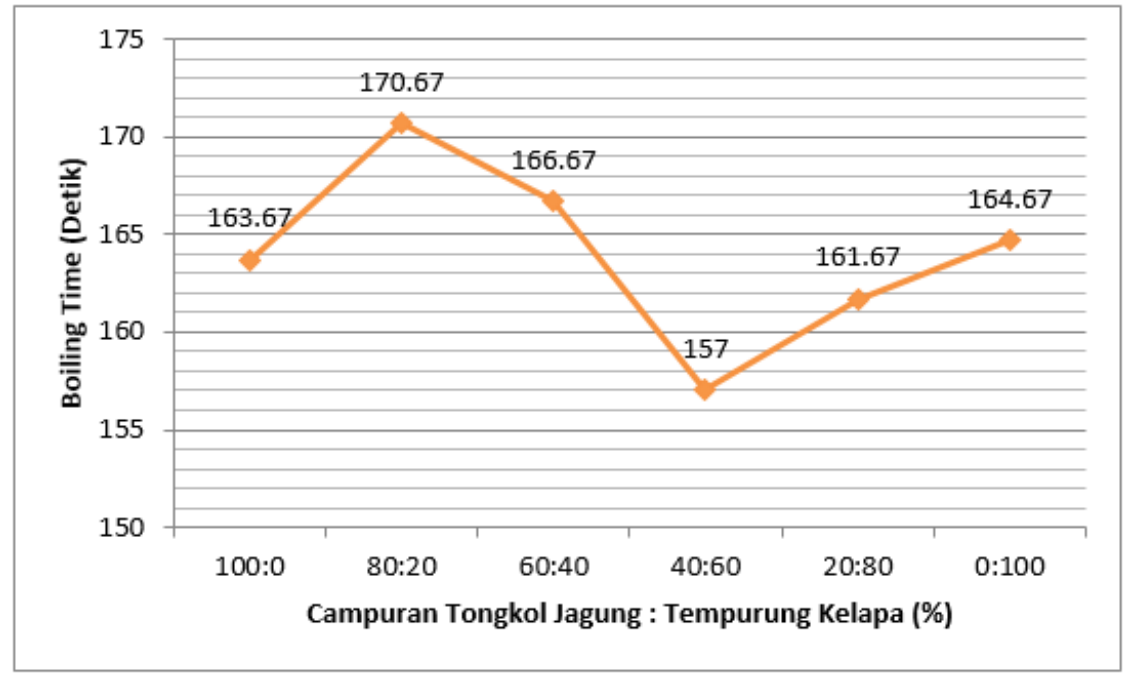

Gambar 8. Hubungan variasi campuran tongkol jagung dan tempurung kelapa terhadap Boiling Time (BT).

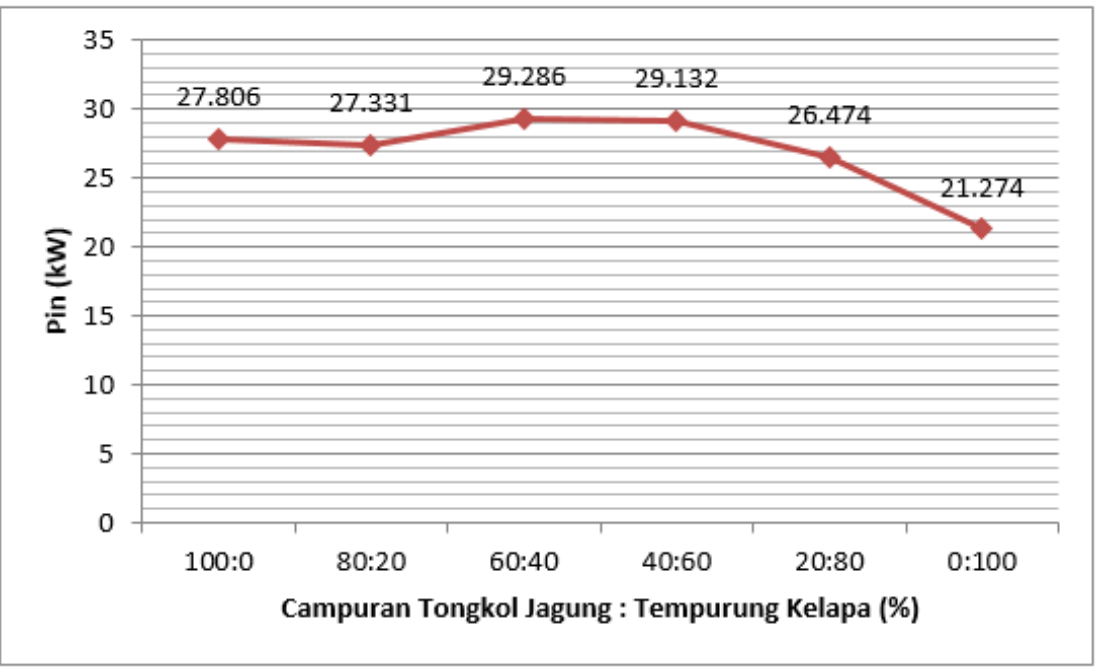

Gambar 9. Hubungan varasi campuran tongkol jagung dan tempurung kelapa terhadap $\mathrm{P}_{\text {in }}$.

c. Daya bersih $\left(\mathrm{P}_{\text {out }}\right)$

Daya bersih $\left(\mathrm{P}_{\text {out }}\right)$ adalah perbandingan antara jumlah energi yang digunakan untuk menaikkan suhu air dengan lamanya waktu untuk mencapai suhu yang diinginkan (kW).Hubungan variasi campuran tongkol jagung dan tempurung kelapa terhadap $\mathrm{P}_{\text {out }}$ digambarkan dengan grafik yang dapat dilihat pada gambar 10 .

Pada gambar 10 menunjukkan bahwa variasi campuran tongkol jagung dan tempurung kelapa tidak memiliki pengaruh yang signifikan terhadap daya bersih yang dihasilkan dari proses pembakaran pada tungku biomassai ini. Daya bersih yang dihasilkan pada masing - masing variasi campuran bahan bakar hampir sama besarnya. Daya bersih terbesar terjadi pada campuran $40 \%$ tongkol jagung dan $60 \%$ tempurung kelapa yaitu 1,828 kW. Sedangkan daya bersih terkecil terjadi pada $80 \%$ tongkol jagung dan 20\% tempurung kelapa yaitu 1,683 kW. Hal ini disebabkan karena semakin besar daya pembakaran yang dihasilkan oleh tungku maka semakin besar pula daya bersinnya.

Pada gambar 10 menunjukkan bahwa variasi campuran tongkol jagung dan tempurung kelapa tidak memiliki pengaruh yang signifikan terhadap daya bersih yang dihasilkan dari proses pembakaran pada tungku biomassai ini. Daya bersih yang dihasilkan pada masing - masing variasi campuran bahan bakar hampir sama besarnya. Daya bersih terbesar terjadi pada campuran $40 \%$ tongkol jagung dan $60 \%$ tempurung kelapa yaitu 1,828 kW. Sedangkan daya bersih terkecil terjadi pada $80 \%$ tongkol jagung dan 20\% tempurung kelapa yaitu 1,683 kW. Hal ini disebabkan karena semakin besar 
daya pembakaran yang dihasilkan oleh tungku maka semakin besar pula daya bersihnya.

d. Kehilangan daya $\left(\mathrm{P}_{\text {loss }}\right)$

Kehilangan daya $\left(\mathrm{P}_{\text {loss }}\right)$ adalah kehilangan daya pada tungku biomassai. $P_{\text {loss }}$ didapatkan dari hasil perhitungan dari daya input dan daya output yang dihasilkan tungku biomassai dengan variasi campuran tongkol jagung dan tempurung kelapa. Hubungan variasi campuran tongkol jagung dan tempurung kelapa terhadap Ploss digambarkan dengan grafik yang dapat dilihat pada Gambar 11.

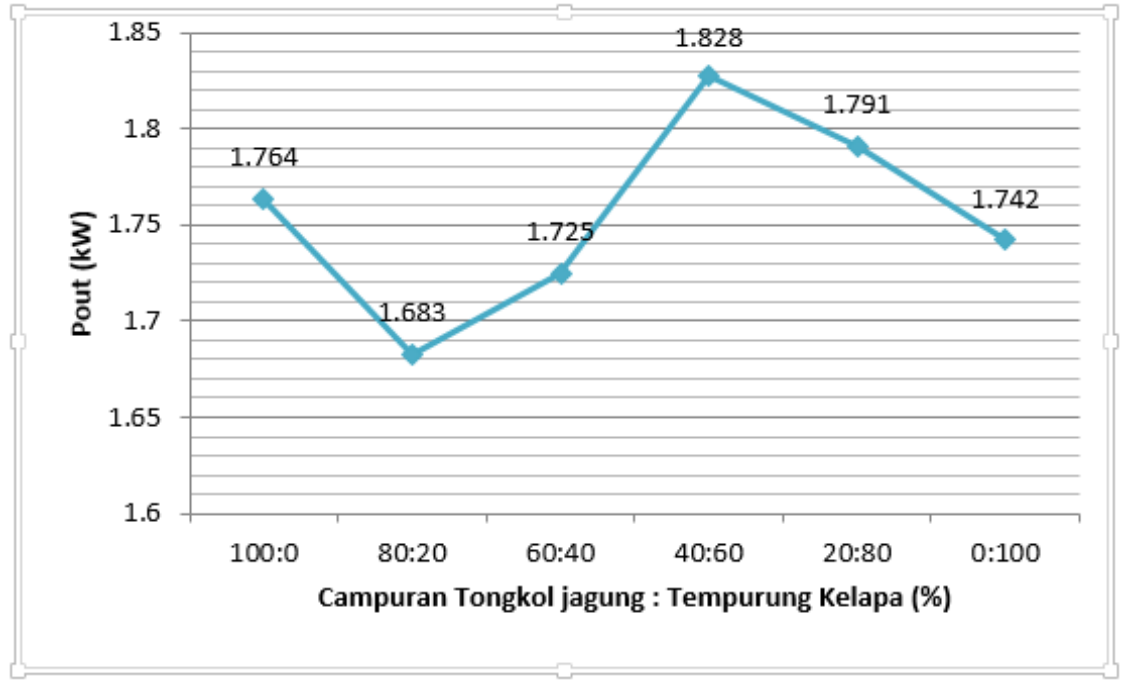

Gambar 10. Hubungan variasi campuran tongkol jagung dan tempurung kelapa terhadap $\mathrm{P}_{\text {out }}$.

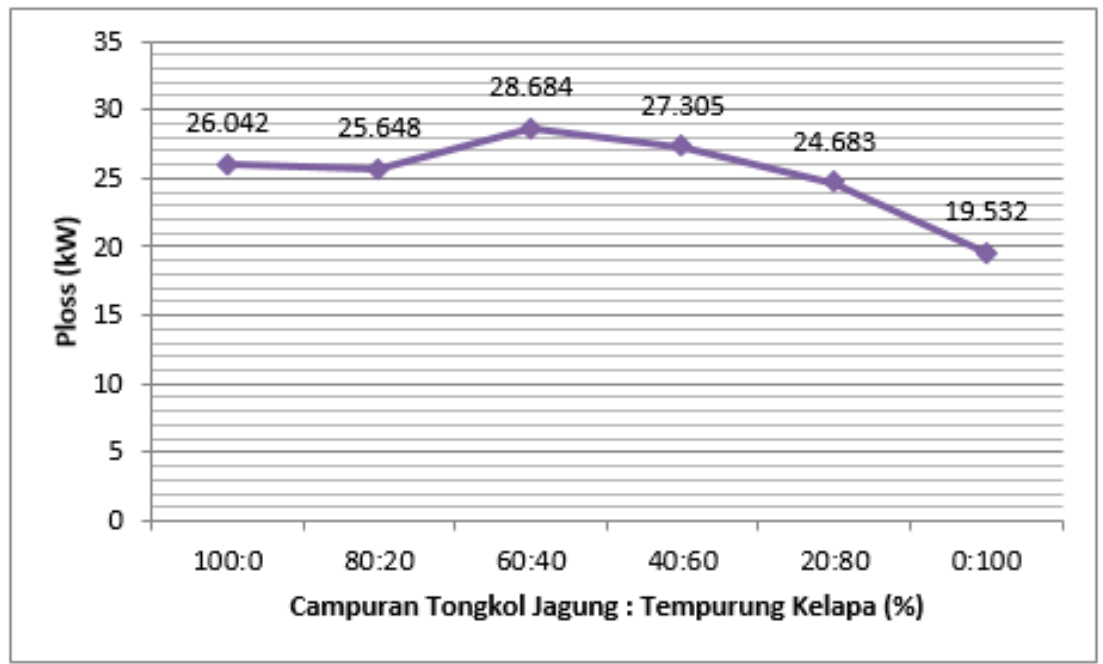

Gambar 11. Hubungan variasi campuran tongkol jagung dan tempurung kelapa terhadap $\mathrm{P}_{\text {loss }}$.

Pada gambar 11, Kehilangan daya pada tungku biomassai di pengaruhi oleh campuran tongkol jagung dan tempurung kelapa sebagai bahan bakar. Kehilangan daya terbesar terjadi pada campuran $60 \%$ tongkol jagung dan $40 \%$ tempurung kelapa yaitu 28,684 kW. Sedangkan kehilangan daya terkecil terjadi pada $100 \%$ tempurung kelapa yaitu 19,532. Hal ini disebabkan karena semakin besar daya yang dihasilkan oleh tungku maka semakin besar pula kehilangan daya yang terjadi, serta banyaknya daya yang terbuang kelingkungan akibat nyala api yang menyebar sehingga tidak terfokus kealat masak. Kehilangan panas pada tungku dikarenakan laju aliran yang tinggi sehingga panas yang dihasilkan terbawa aliran udara, besarnya nilai kehilangan panas ini juga dipengaruhi oleh perbedaan suhu badan tungku dan suhu lingkungan. Semakin tinggi perbedaan suhu semakin tinggi nilai kehilangan panas tersebut. 


\section{Efisiensi tungku biomassa ( $n$ )}

Efisiensi tungku adalah perbandingan antara energi yang digunakan pada pemanasan air dengan energi panas yang terkandung pada bahan bakar. Setelah mendapatkan daya yang dihasilkan untuk memanaskan air dan besarnya daya pembakaran maka efisiensi dari tungku biomassai dapat ditemukan.Hubungan variasi campuran tongkol jagung dan tempurung kelapa terhadap efisiensi proses tungku biomassai digambarkan dengan grafik yang dapat dilihat pada Gambar 12.
Dari gambar 12 diatas terlihat bahwa efisiensi tungku biomassai pada pemanas air untuk masing - masing variasi campuran tongkol jagung dan tempurung kelapa sebagai bahan bakar menunjukkan bahwa variasi bahan bakar memengaruhi efisiensi tungku. Nilai efisiensi yang terbesar terjadi pada $100 \%$ tempurung kelapa yaitu $8,19 \%$. Sedangkan nilai efisiensi terkecil terjadi pada campuran $60 \%$ tongkol jagung dan $40 \%$ tempurung kelapa yaitu $5,89 \%$.

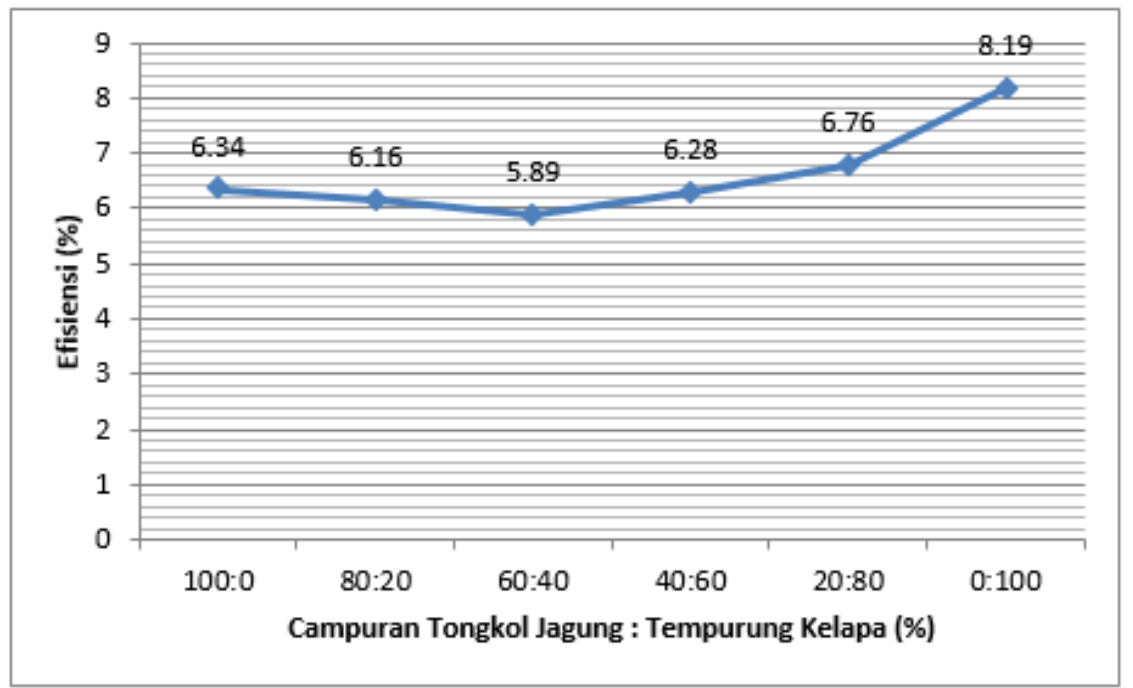

Gambar 12. Hubungan variasi campuran tongkol jagung dan tempurung kelapa terhadap efisiensi proses tungku biomassai

Hal ini disebabkan karena nilai dari efisiensi tungku tergantung dari jumlah konsumsi bahan bakar yang digunakan pada proses pembakaran. Selain itu nilai efisiensi juga tergantung dari kalor bahan bakar yang digunakan.Pada campuran $60 \%$ tongkol jagung dengan $40 \%$ tempurung kelapa memiliki daya pembakaran paling tinggi yaitu 29,286 kW, sedangkan daya bersih yang diterima oleh air hanya sebesar $1,725 \mathrm{~kW}$ yang mengakibatkan besarnya daya yang hilang selama proses pemanasan air adalah $28,684 \mathrm{~kW}$. Hal ini yang menyebabkan efisiensi tungku menjadi rendah yaitu 5,89\%. Lain halnya dengan bahan bakar $100 \%$ tempurung kelapa, yang memiliki daya pembakaran paling rendah yaitu $21,274 \mathrm{~kW}$ dan daya bersihnya adalah $1,742 \mathrm{~kW}$, sehingga kehilangan daya nya terkecil dibandingkan campuran bahan bakar yang lain yaitu 19,532 kW. Hal ini yang mengakibatkan efisiensi tungku menjadi lebih tinggi dibandingkan dengan campuran bahan bakar yang lainnya yaitu sebesar $8,19 \%$. Daya pembakaran yang tinggi menyebabkan perbedaan suhu ruang pembakaran tungku dengan suhu lingkungan menjadi besar, sehingga kehilangan daya pada tungku lebih tinggi yang mengakibatkan semakin rendahnya efisiensi tungku.

\section{KESIMPULAN}

Berdasarkan hasil perhitungan dan analisa data yang telah dilakukan pada bab sebelumnya, maka dapat ditarik kesimpulan diantaranya :

1. Dari hubungan antara variasi bahan bakar campuran tongkol jagung dan tempurung kelapa dengan karakteristik dan efisiensi tungku, didapatkan bahwa Operating Time terbesar (1317,33 Detik), Fuel Consumption Rate terkecil $(2,249 \mathrm{Kg} / \mathrm{Jam})$, Kehilangan Daya terkecil $(19,532 \mathrm{~kW})$ dan Efisiensi terbesar $(8,19 \%)$ terjadi pada variasi $0 \%$ tongkol jagung : 100\% tempurung kelapa. Sedangkan Boiling Time tercepat (157 Detik) dan Daya Bersih terbesar $(1,828 \mathrm{~kW})$ terjadi pada variasi $40 \%$ tongkol jagung : $60 \%$ tempurung kelapa. Kemudian Daya Pembakaran terbesar $(29,286 \mathrm{~kW})$ terjadi 
pada $60 \%$ tongkol jagung : $40 \%$ tempurung kelapa.

2. Dalam hal ini peneliti memilih variasi bahan bakar 40:60 \% memberikan nilai boiling time yang paling baik walaupun efisiensi tungku tergolong masih rendah dan daya bersih yang dihasilkan terbesar. Dengan variasi bahan bakar tersebut maka sifat dan karakteristik bahan bakar akan saling melengkapi dimana tongkol jagung lebih mudah terbakar dan membantu mempercepat terbakarnya batok kelapa, ketika tongkol jagung sudah mulai habis maka nyala didalam ruang bakar masih tetap tinggi diakibatkan oleh terbakarnya batok kelapa.

3. Dalam penelitian ini kompor yang didesain menggunakan bahan bakar biomassa masih memiliki efisiensi yang rendah, karena karakteristik biomassa dengan density yang berbeda-beda, ada yang cepat terbakar, dan sebaliknya, hal ini bisa diperbaiki dengan membuat bahan biomassa tersebut menjadi serbuk dan di cetak dengan ukuran mesh yang sama.

\section{UCAPAN TERIMAKASIH}

Penulis pada kesempatan ini mengucakan terimakasih kepada semua pihak yang membantu baik berupa materi maupun pikiran terutama mahasiswa teknik mesin, terima kasih juga penulis kepada kemenristekdikti melalui Program PPT tahun 2017 dan jurusan teknik mesin atas pasilitas yang diberikan.

\section{DAFTAR NOTASI}

BT : Boiling Time (Detik)

$\mathrm{Cp} \quad$ : Kalor jenis air $\left(\mathrm{Kj} / \mathrm{Kg}^{\circ} \mathrm{C}\right)$

FCR : Fuel Consumption Rate (Kg/Jam)

$L H V b b$ : Nilai kalor bawah bahan bakar $\left(\mathrm{Kj} / \mathrm{Kg}^{\circ} \mathrm{C}\right)$

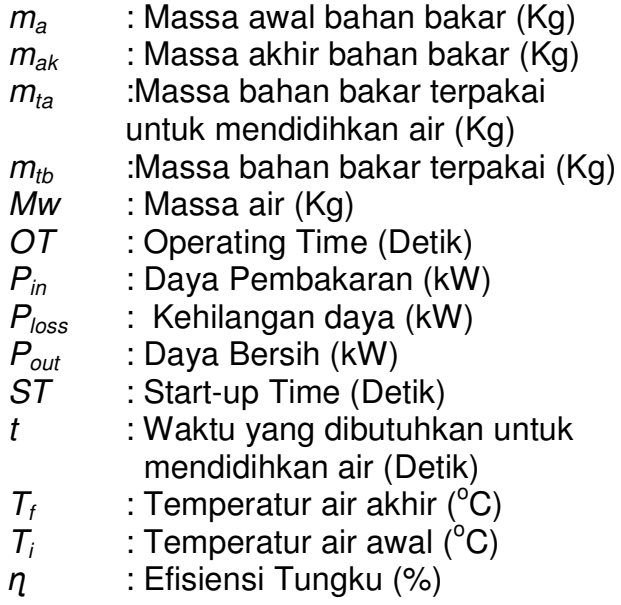

\section{DAFTAR PUSTAKA}

BSN., 2013, Kinerja tungku biomassa, Gedung Manggala Wanabakti, Jakarta.

Joniarta I.W., Alit I.B., Sutanto R., Nurcahyati, 2014, Unjuk kerja kompor biomassai dengan bahan bakar biomassa ranting dan limbah potongan kayu kering, Laporan Penelitian Lembaga Penelitian Universitas Mataram, Mataram.

Mirmanto, Mulyanto A., Hidayatullah, L.R., 2017, Hubungan ketinggian dan diameter lubang udara tungku pembakaran biomassa dan efisiensi tungku, Jurnal Teknik Mesin (JTM), 06(4), 225-230.

Tahir M., Kasim R., Bait Y., 2013, Uji performansi desain terintegrasi tungku biomassa dan penukar panas, Fakultas Pertanian, Universitas Negeri Gorontalo.

Widardo, Suryanta, 1995, Membuat bioarang dari kotoran lembu, cetakan Ke-6 tahun 2008, Kanisius, Bogor.

www.programunggulan.ntbprov.go.id diakses 15 Mei 2017 